\title{
Zeszyty PRASOZNAWCZE
}

Kraków 2018, T. 61, nr 3 (235), s. 449-459

doi:10.4467/22996362PZ.18.027.10129

www.ejournals.eu/Zeszyty-Prasoznawcze/

\section{LEXICAL MEANS WHICH INDICATE THE (IN)CREDIBILITY OF MEDIA CONTENTS (A PSYCHOLINGUISTIC EXPERIMENT)}

\author{
ANDREANA EFTIMOVA (iD http://orcid.org/0000-0001-9232-7243 \\ Sofia University "St. Kliment Ohridski”
}

\begin{abstract}
In reference to the frequent breach of Paul Grice's maxim about truth, this article seeks answers to the questions: do Bulgarians recognize unreliable information in the media and what is the role of linguistic means in the process of interpreting the truth of the media contents? It discusses the results of an experiment aimed at verifying the roles of three groups of language expressions in forming a sense of credibility or unreliability of journalistic information among recipients.
\end{abstract}

Keywords: credibility, language expressions, journalistic texts

\section{Linguistics of the Truth and the Post-truth}

In his article "The Linguistics of Lying" Harald Weinrich emphasizes that people lie with the means of language, and therefore linguistics can explain what is going on in the language when the truth turns into a lie (Weinrich 1987, p. 44). In his theory of conversation, Paul Grice reflects on what is being communicated, what is or is not used in our speech, and what is understood and implied in the given context (see Grice 1991). These dilemmas are essential in order to clarify the issues of the truthfulness of information. The maxims of conversation put forward by Grice in his "Theory of Implications", which are united by the principle of 
cooperation between the participants in a conversation, can be used to elucidate the matters that modern media is all about - truth and fabrication, post-truth and fake news. The conversion maxims are as follows:

1. Maxim about the quantity (make your contribution as informative as is required, do not make your contribution more informative than is required);

2. Maxim about the quality (do not say what you believe to be false or that for which you lack adequate evidence);

3. Maxim about the relation, or the maxim about the attitude of the addressee towards the statement (be relevant);

4. Maxim about the manner (avoid obscurity of expression, avoid ambiguities, be brief (avoid unnecessary prolixity, be orderly) (Grice 1975, pp. 64-65, see also Eftimova 2016, s. 68).

Of particular importance to the problem about the credibility of the content is the second maxim about the quality of the contribution. The issue, according to Jocelyne V. Marrelli, has several aspects. Among them, two are related to the maxim about the quality:

- the correlation between the cognitive state of the speaker (sincerity) and the content of the contribution;

- the correlation between the cognitive state of the speaker (adequate awareness) and the content of the contribution (see more in detail in Marrelli 2002, pp. 1-48; Nicolova 2016, pp. 24-35).

Let's have a look at the issues which these two aspects bring about. The correlativity between the speaker's sincerity and the veracity of the speech is to measure the correspondence between the speaker's actual thoughts and the meaning behind the message. It is a complex task, however it's established that there are areas of social interaction in which the maxim about the quality of communication, when it states that what is not certain should not be said, is neglected. Journalism is such a field as well. Due to the pursuit of sensationalism, the contributions are characterized as shocking, sensational, scandalous, without their addressees believing in these characteristics. The pursuit of sensation forces them to break the rule of sincerity.

Reflecting the adequate awareness of the speaker in the contribution is also vital in order to assess the credibility of the information. It stands to reason that the speaker's awareness is limited due to a variety of factors (time, place, educational and cultural standard, etc.) and language provides means to make the audience aware of the level of speaker's understanding. These devices are called protective performatives or hedged performatives (see Nicolova 2016, pp. 30-31), or devices of denoting fuzzy logic (Lakoff 1973), modifiers of the responsibility of the writer (Markkanen, Schröder 1997, pp. 5-6).

Such protective performatives indicate, for instance, the source of the information (e.g. so claim relatives of the victim, according to eyewitnesses, etc.) or the confidence of the speaker in his adequate awareness about the event (e.g. probably, most likely, possibly, etc.). Such expressions "indicate a claim's ambiguity 
and reduce it's author's responsibility for the veracity of the proposition" (Nicolova 2016, p. 31). In journalism, they may be deliberately misleading the addressee - they may seek to convince him of the truthfulness of the information, which is not actually credible, by indicating an irrelevant or inaccurate/indistinct source or to express confidence (or uncertainty) in the credibility of the information. Ralph Keys, in his book "The Post-Truth Era" (2004), as well as Stephen Colbert, popularize the word "post-truth" in its meaning "seemingly true even when it's not the truth" (OLD 2016), which fully corresponds to the manipulative retreat from the maxim about the authenticity when stating an irrelevant/indistinct/inaccurate source or a fake (non)confidence in the credibility of the information.

Therefore the maxim about the quality of the information, which should guarantee the veracity of the communication, is neglected for various reasons - due to the inaccuracy of the speaker in certain activities ${ }^{1}$, including journalism, owing to the speaker's awareness and way of expression.

\section{A study of the authentication of information via language expressions in a journalistic text}

The violation of the maxim of truth in its various aspects has raised interest in seeking answers to the question whether the Bulgarian recognizes unreliable information in the media and the role of linguistic means in the process of interpreting the truth of the media contents. The results of a study by the sociological agency Alpha Research commissioned by the Konrad Adenauer Foundation, announced by the BTV (2017), indicate Bulgarians have the skills to recognize fake news.

The results, however, exclude observations on the recipients' interpretation of the content and type of specific media texts. Therefore, in this article, I present an experiment aimed at the verification of the role of some groups of language expressions in creating a sense of credibility or incredibility of journalistic information.

Three groups of expressions according to the above-mentioned aspects of the quality maxim of the contribution (do not say what you believe to be false or that for which you lack adequate evidence) were chosen - one set of expressions is linked to the correlation between the cognitive state of the speaker's sincerity and the content of the statement, and the other two sets - to the correlation between the cognitive state of the speaker adequate awareness and the content of the message, while the subgroups contain expressions (protective performatives) of the source of the information and of the amount of confidence of the veracity of the speaker's statement.

1 R. Nicolova points out "diplomacy, political discourse of manipulative nature in the media and in institutions, bureaucratic speech, patient-to-patient communication, army communication, police, to some extent in the court and in other places with different activities of the participants in the communication" (Nicolova 2016, p. 29, see also in Dimitrova 2009, pp. 191-215). 


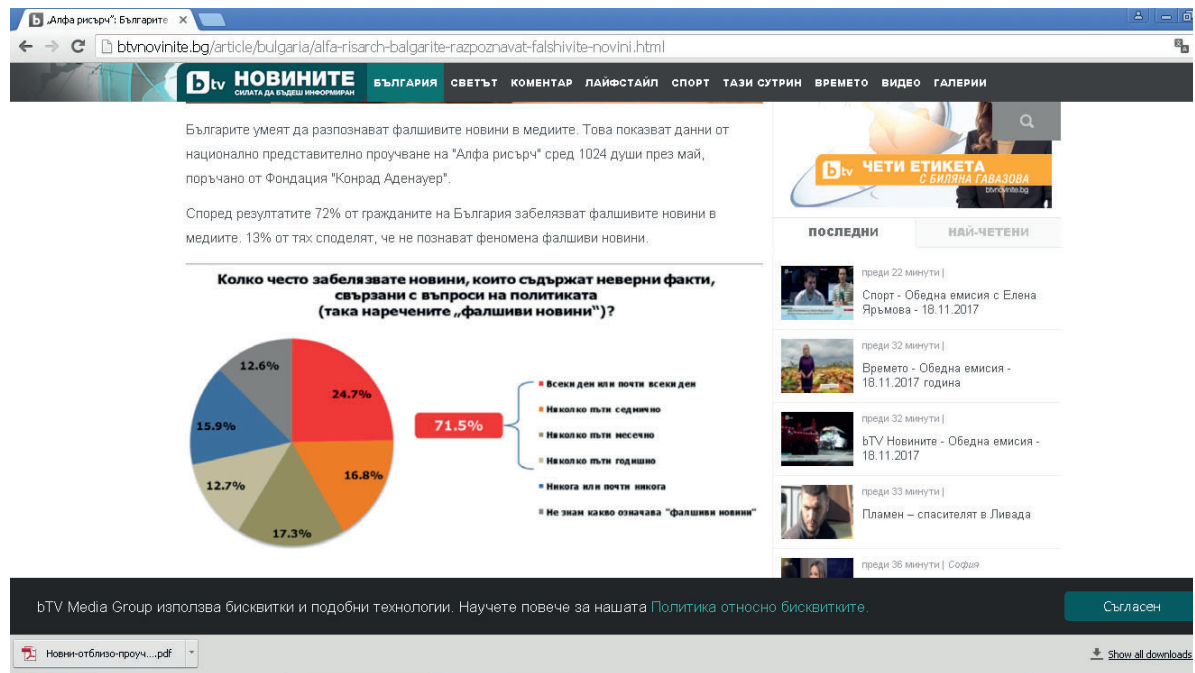

Illustration 1. A visual representation of the results of a study by the Alpha Research Sociological Agency commissioned by the Konrad Adenauer Foundation on the Bulgarians' skills to recognize fake news

\begin{tabular}{ll|l} 
Expressions which & Breaking \\
determine the type of & $\longrightarrow$ \\
information & $\begin{array}{l}\text { Scandalous } \\
\text { Sensational } \\
\text { Shocking }\end{array}$
\end{tabular}

\begin{tabular}{ll|} 
Expressions \\
characterizing the source \\
of the information
\end{tabular}$\quad \begin{aligned} & \text { Claimed a loved one, a relative, a friend; } \\
& \text { Claimedindividuals familiar with the case } \\
& \text { Accoring to eyewitnesses } \\
& \text { According to our source } \\
& \text { The source wished to remain anonymous }\end{aligned}$

\begin{tabular}{l}
$\begin{array}{l}\text { Expressions reflecting } \\
\text { the confidence of the } \\
\text { speaker/writer in the } \\
\text { credibility of the } \\
\text { information }\end{array}$ \\
$\begin{array}{ll}\text { It is probable, perhaps, it is possible, etc. } \\
\text { Definitely, without a doubt, absolutely } \\
\text { correct, etc. }\end{array}$ \\
\hline
\end{tabular}

Figure 1. Typology of the lexical expressions signifying credibility or incredibility

Source: Author's own study with reference to Grice (1975). 
As a result of this typology, a questionnaire was issued, containing instructions for the respondents (see Table 1).

Table 1. Illustration of a matrix of the questionnaire

Identify what the listed language expressions express. Tick off your answer with a $\sqrt{ }$.

\begin{tabular}{|l|l|l|l|}
\hline & $\begin{array}{l}\text { Credibility of the } \\
\text { information }\end{array}$ & $\begin{array}{l}\text { Incredibility of } \\
\text { the information }\end{array}$ & $\begin{array}{l}\text { Doesn't affect the } \\
\text { credibility }\end{array}$ \\
\hline Breaking & & & \\
\hline Scandalous & & & \\
\hline Sensational & & & \\
\hline Shocking & & & \\
\hline $\begin{array}{l}\text { Claimed a loved one / } \\
\text { a relative / a friend }\end{array}$ & & & \\
\hline $\begin{array}{l}\text { Claimed individuals } \\
\text { familiar with the case }\end{array}$ & & & \\
\hline According to eyewitnesses & & & \\
\hline According to our source & & & \\
\hline $\begin{array}{l}\text { The source wished to } \\
\text { remain anonymous }\end{array}$ & & & \\
\hline $\begin{array}{l}\text { It is probable, perhaps, it is } \\
\text { possible, etc. }\end{array}$ & \\
\hline $\begin{array}{l}\text { Definitely, without a doubt, } \\
\text { absolutely correct, etc. }\end{array}$ & & & \\
\hline
\end{tabular}

Source: Author's own research.

The experiment was conducted among 51 students of the course "Journalism, Public Relations and Book Publishing". 


\section{Results of the conducted study}

The results are illustrated in a table, and are organized in graphs according to the three lexical groups described above. Table $2^{2}$ is a thorough representation of how well the words and phrases in the three lexical groups are evaluated as ways to express credibility or unreliability.

Table 2. Results of the study - total answers of respondents

\begin{tabular}{|l|l|l|l|}
\hline & $\begin{array}{l}\text { Credibility of the } \\
\text { information }\end{array}$ & $\begin{array}{l}\text { Incredibility of } \\
\text { the information }\end{array}$ & $\begin{array}{l}\text { Doesn't affect the } \\
\text { credibility }\end{array}$ \\
\hline Breaking & 16 & 10 & 26 \\
\hline Scandalous & 11 & 19 & 23 \\
\hline Sensational & 12 & 20 & 21 \\
\hline Shocking & 7 & 20 & 25 \\
\hline $\begin{array}{l}\text { Claimed a loved one / } \\
\text { a relative / a friend }\end{array}$ & 31 & 13 & 7 \\
\hline $\begin{array}{l}\text { Claimed individuals familiar } \\
\text { with the case }\end{array}$ & 28 & 15 & 8 \\
\hline According to eyewithnesses & 30 & 18 & 3 \\
\hline According to our source & 27 & 18 & 6 \\
\hline $\begin{array}{l}\text { The source wished to remain } \\
\text { anonymous }\end{array}$ & 17 & 18 & 17 \\
\hline $\begin{array}{l}\text { It is probable, perhaps, it is } \\
\text { possible, etc. }\end{array}$ & 5 & 33 & 14 \\
\hline $\begin{array}{l}\text { Definitely, without a doubt, } \\
\text { absolutely correct, etc. }\end{array}$ & 43 & 3 & 5 \\
\hline
\end{tabular}

Source: Author's own research.

2 Explanation of quantitative results in the table:

1 respondent did not give an answer about the first four words.

1 respondent has not responded to "according to eyewitnesses".

1 respondent has not responded to "claimed a loved one, a relative, a friend".

1 respondent gave the opposite answers to "the source wished to remain anonymous". It is reflected in the questionnaire.

Typically, respondents who answered that "it is probable, perhaps, it is possible, etc.", are an indication of authenticity, claim that "definitely, without a doubt, absolutely correct, etc."are an indication of unreliability, and vice versa.

1 respondent has given two answers - "incredibility of the information" and "doesn't affect the credibility" - for "according to eyewitnesses". It is reflected in the questionnaire.

1 respondent has given two answers - "incredibility of the information" and "doesn't affect the credibility" - for "claimed a loved one, a relative, a friend". It is reflected in the questionnaire.

1 respondent has given two answers - "incredibility of the information" and "doesn't affect the credibility" - "it is probable, perhaps, it is possible", etc. It is reflected in the questionnaire.

1 respondent has given two answers - "incredibility of the information" and "doesn't affect the credibility" - "scandalous" and "sensational". It is reflected in the questionnaire.

1 respondent has responded positively with the three answers to the first four words. 
It stands to reason that the expressions characterizing the confidence of the speaker in the credibility of the information (also refer to Figure 1) are at the positive end of the confidence scale. This shows great confidence in the journalist's sincerity, which indicates the authenticity of the statement with linguistic means, standing witness to their own confidence in the truthfulness of the information. Thus, the widely shared view of undermined trust in the journalist, as well as research showing new forms of journalism evolving because of the devaluated values in the journalist profession, are all contradicted by another, as can be seen, preserved trust in the journalist and their verification of events and facts.

The addressees do not suppose that signs of confidence in the veracity of the information may be deliberately misleading or reflect the speaker's delusion that he is telling the truth, and those who display uncertainty in the credibility may be an example of sincerity, since the speaker indicates, with their help, that she/he is not sure about her/his statement. The largest percentage of respondents reported the characteristics of uncertainty in the attitude of the journalist towards the reliability of the reported information as indicators of unreliable statements. These results lead to the assumption that the respondents trust only the signs of firm confidence in the truth of the information, but often reject the more sincere and solid signs (protective performatives) of doubt in the reliability of the reported information. This conclusion proves that respondents are easily manipulated regarding the truth of the information they receive via the media.

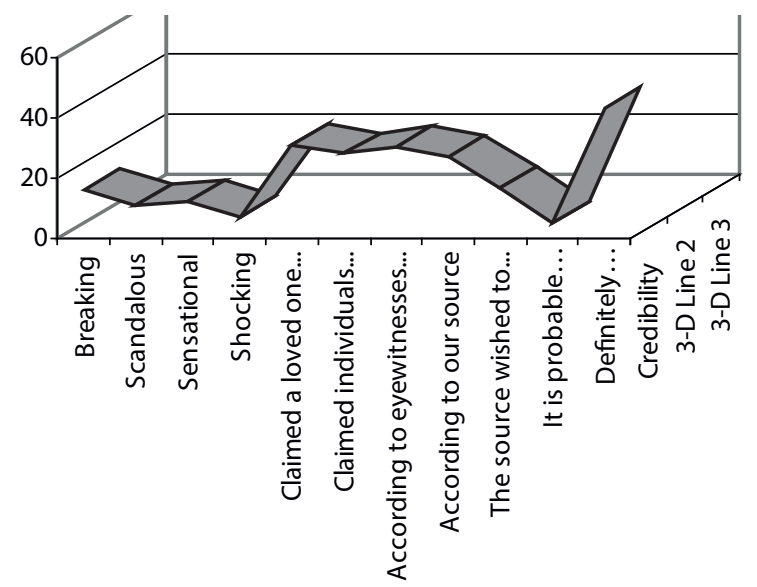

Graph 1. Curve showing the expressions regarding the credibility

Source: Author's own research. 
Analysis of the results according to the three lexical groups

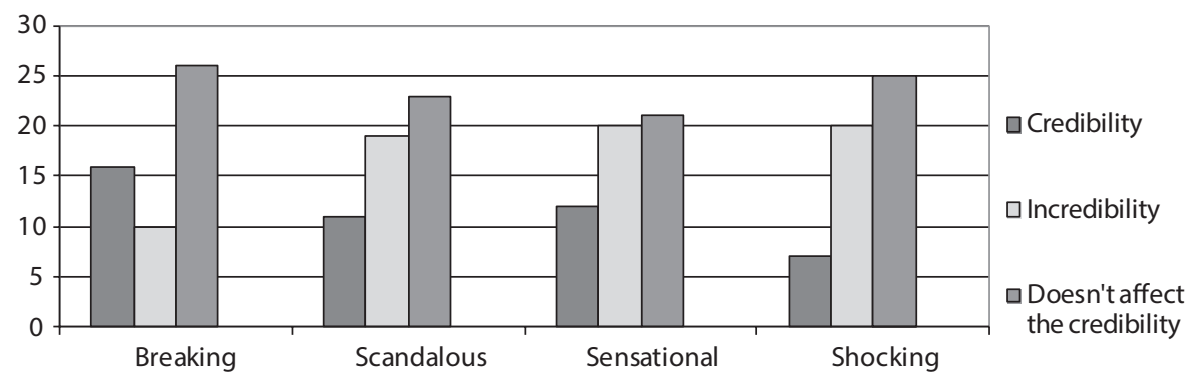

Graph 2. Evaluation of the expressions which determine the type of information

Source: Author's own research.

Respondents evaluate the expressions in this group as having no effect to the authenticity of the information. The ratio between the ratings of the credibility and incredibility is quite interesting. Only "breaking" received a high number of votes when it comes to credibility, higher than the rating of the respondents who identify it as a sign of unreliable information. The other three expressions are more likely to be considered signs of incredibility rather than proving the authenticity of the journalistic text. This indicates that their presence in journalistic content may undermine the trust of the audience. The presence of these adverbs, which emphasize the sensationalism of journalistic materials, is a common practice: "It is a well-established practice in websites and in televisions to envelop materials with sensational titles. Often times the sensationalism in the title makes up for the missing sensation in the content itself. Generally, headlines, especially those of some websites, emphasize the «missing» information in the text - scandalous, breaking, shocking" (Angelova, Popova, Neikova 2016, p. 30). The questionnaire makes it obvious that recipients are already aware of this commonly used manipulative technique, and tend to assess these expressions as signs of incredibility, or tend to ignore them as insignificant in terms of the authenticity of the information. 


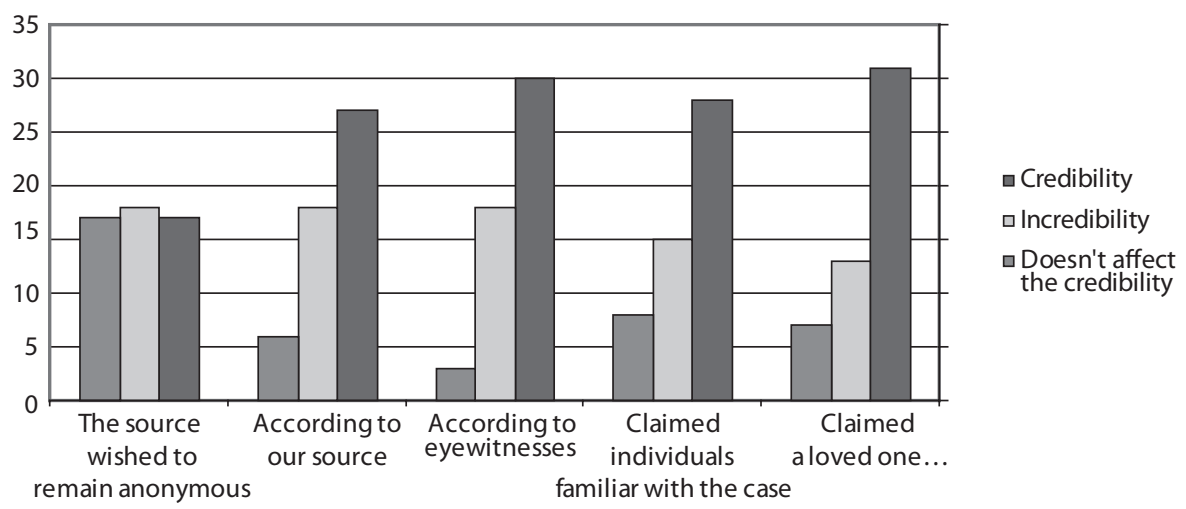

Graph 3. Evaluation of the expressions characterizing the source of the information

Source: Author's own research.

The expression "claimed a loved one/a relative/a friend" has received the most votes in terms of credibility, followed by the phrases "according to eyewitnesses", "claimed individuals familiar with the case" and "according to our source". All expressions state the source of the information inaccurately and vaguely, which mostly suggests that the speaker is inadequately informed or is attempting to manipulate the recipient - adding some sort of credibility to otherwise unreliable information. However, in the assessment of the respondents, these expressions are signs of the authenticity of the provided information. The quantitative results of the three responses, in the expression "the source wished to remain anonymous", are so similar that it cannot be concluded whether there is a consensus on the effect of this phrase to the credibility of the information in the journalistic text.

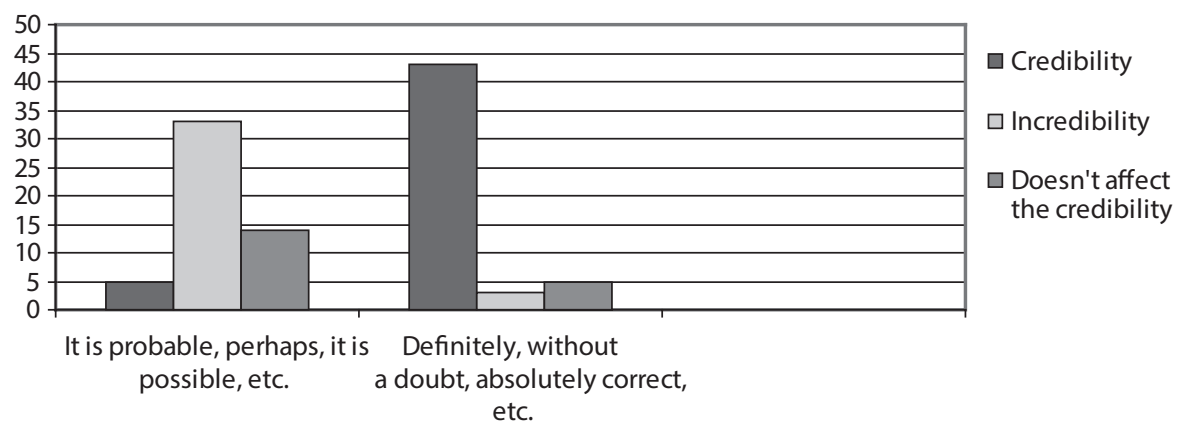

Graph 4. Evaluation of the expressions, reflecting the confidence of the speaker/writer

Source: Author's own research. 
The results for this lexical group have already been discussed (in the explanation regarding Table 2). These expressions are the most popular among all expressions in the quantitative dimensions of the high (or respectively - low) credibility of the information. It is especially interesting that a certain group of expressions, reflecting the certainty or uncertainty of the speaker in the veracity of the information ("it is possible ..."), is also highly regarded as irrelevant to the authenticity of the information. Similar doubts about the group of expressions, reflecting the speaker's confidence in the truth of what was said, have received an insignificant amount of answers by the respondents.

\section{Summary}

The first group of expressions does not affect the credibility (refer to Graph 2). The adverb "ekskluzivno" ("breaking") creates a sense of authenticity of the information, while the adverbs "skandalno" ("scandalous"), "senzacionno" ("sensational") and "shokiraskto" ("shocking") - of unreliability of the content. This leads to the conclusion that recipients have already been aware of this commonly used manipulative technique for adding sensationalism to journalistic materials and tend to assess expressions as signs of incredibility, or tend to ignore them as insignificant in terms of the authenticity of the information.

The second group of expressions creates a sense of reliability, although sources are not specified (refer to Graph 3). This shows the audience's trust in the media and a low level of criticality and rigor to the specific mention of the source. Only the expression "the source wished to remain anonymous" is a sign, in the eyes of the recipient of the information, that it may be unauthentic, but the quantities of the three criteria which were evaluated are similar.

The third group of expressions (refer to Graph 4) contains a paradox. It is possible, via the uncertainty in the communicated information, that the speaker/writer has remained true to the fact that the information is not accurate. Conversely, confidence may be used to conceal false information. Despite all of this, respondents point out the expressions of confidence as signs of credibility, and the expressions of hesitation as signs of incredibility. Precisely this is a proof of the undeniable trust in journalist as a guarantor of the legitimacy of the information.

Perhaps, this is why the issue regarding the post-truth and the fake news in the media and in every social activity is so important to every society. Journalists control the possibilities that language provides us with, in order to control the truth, and the truth, according to Bollinger, is that property of the language which allows us to be informed, since it is based on the reader's readiness to share the known information (Bollinger 1987, pp. 29-30). 


\section{References}

Angelova V., Popova Zh., Nejkova M. (2016). Novini... otblizo. Sofia: AEZH I “Amerika za Balgarija".

Bolindger D. (1987). Istina - problema lingvisticheskaja. In: V.V. Petrov (ed.). Jazjik i modelirovanie socialnogo vzaimodejstvija (pp. 23-43). Moskva: Progress.

BTV (2017). Alpha Research: Bulgarians Recognize False News. BTV The News. 27.06.2017 [http://btvnovinite.bg/article/bulgaria/alfa-risarch-balgarite-razpoznavat-falshivite-novini. html; 28.04.2018].

Dimitrova S. (2009). Lingvistichna pragmatika. Sofia: Veles.

Eftimova A. (2016). Dvojstvenijat ezik v mediite: ezikat na politicheskata korektnost vs ezika na omrazata. Sofia: Prosveta.

Grice P. (1975). Logic and Conversation. In: P. Cole, J. Morgan (eds.). Speech Acts (pp. 41-58). New York: Academic Press.

Grice P. (1991). Studies in the Way of Words. London: Harvard University Press.

Nicolova R. (2016). Za narushenijata na maksimite na Grajs - maksima za istinnostta (Predvaritelna versija). Forum "Balgarska gramatika" 2. Gramatika i pragmatika (pp. 24-35). Veliko Tarnovo: UI "Sv. sv. Kiril i Metodij”.

Lakoff G. (1973). Hedges: A Study in Meaning Criteria and the Logic of Fuzzy Concepts. Journal of Philosophical Logic, vol. 4, pp. 458-508. Available from [https://georgelakoff. files.wordpress.com/2011/01/hedges-a-study-in-meaning-criteria-and-the-logic-of-fuzzyconcepts-journal-of-philosophical-logic-2-lakoff-19731.pdf; 28.04.2018].

Markkanen R., Schröder H. (1997). Hedging: A Challenge for Pragmatics and Discourse Analysis. In: R. Markkanen, H. Schröder (eds.). Hedging and Discourse: Approaches to the Analysis of a Pragmatic Phenomenon in Academic Texts (pp. 3-20). Berlin/New York: de Gruyter.

Marrelli J.V. (2002). Truthfulness. In: J. Verschueren, J.-O. Östman, J. Blommaert, Ch. Bulcaen (eds.). Handbook of Pragmatics 2002 (pp. 1-48). Amsterdam/Philadelphia: John Benjamins.

OLD (2016). Oxford Living Dictionaries. Word of the Year 2016 is..., Oxford Living Dictionaries. Oxford University Press [https://en.oxforddictionaries.com/word-of-the-year/word-ofthe-year-2016; 28.04.2018].

[Weinrich 1987] Vajnrih H. (1987). Lingvistika lzhi. In: V.V. Petrov (ed.). Jazjik i modelirovanie socialnogo vzaimodejstvija (pp. 44-87). Moskva: Progress.

\section{STRESZCZENIE}

W nawiązaniu do częstego naruszania maksymy jakości Paula Grice’a o prawdzie podjęto próbę odpowiedzi na pytania: czy Bułgarzy rozpoznają niewiarygodne informacje w mediach oraz jaka jest rola środków językowych w procesie interpretowania prawdy dotyczącej zawartości mediów? Omówiono wyniki eksperymentu mającego na celu sprawdzenie roli trzech grup wyrażeń językowych w kształtowaniu poczucia wiarygodności lub zawodności informacji dziennikarskich wśród odbiorców.

Słowa kluczowe: wiarygodność, wyrażenia językowe, teksty dziennikarskie 